\title{
Gene expression of CCL8 and CXCL10 in peripheral blood leukocytes during early pregnancy in cows
}

\author{
Ryosuke Sakumoto ${ }^{1 *}$, Kosuke Iga ${ }^{2}$, Ken-Go Hayashi ${ }^{1}$, Shiori Fujii ${ }^{1}$, Hiroko Kanahara' ${ }^{1}$, Misa Hosoe ${ }^{3}$
} and Tadashi Furusawa ${ }^{3}$

\begin{abstract}
Background: The aim of the present study was to evaluate CCL8 and CXCL10 expression and its regulatory mechanism in peripheral blood leukocytes (PBLs) at the time of maternal recognition in cows. Blood samples were collected on 14, 15, 16, 17 and $18 \mathrm{~d}$ after artificial insemination (AI). Based on the day of return of estrus, cows were divided into three groups, pregnant $(n=5)$, early embryonic mortality (EEM; $n=5)$ and late embryonic mortality $(L E M ; n=5)$. The gene expression levels in PBLs were assessed with quantitative real-time reverse transcription PCR.

Results: The expression of CCL8 and CXCL10 mRNA in PBLs gradually increased from 14 to $18 \mathrm{~d}$ of pregnant cows and significant differences were observed on $18 \mathrm{~d}(P<0.05)$, whereas no significant changes were observed both in EEM and LEM cows. Interferon-stimulated protein $15 \mathrm{kDa}$ (ISG15), myxovirus-resistance gene (MX) 1 and MX2 mRNA expression in PBLs increased from 14 to $18 \mathrm{~d}$ which was significant on $18 \mathrm{~d}$ of pregnant cows as well as in LEM cows $(P<0.05)$, but no changes were observed in EEM cows. To determine whether the expression of CCL8 and CXCL10 in PBLs was regulated by pregnancy-related substances or not, expression level was assessed after exposure to interferon-t (IFNT) and CCL16. Monocytes, granulocytes and lymphocytes were obtained using density-gradient centrifugation and flow cytometry. The addition of IFNT (100 ng/mL) and CCL16 $(100 \mathrm{ng} / \mathrm{mL})$ to cultured PBLs increased the expression of CCL8 and CXCL10 mRNA $(P<0.05)$. The expression of ISG15, MX1 and MX2 mRNA in PBLs was also stimulated by IFNT and CCL16 $(P<0.05)$.

Conclusions: The expression of CCL8 and CXCL10 genes increased in PBLS during early pregnancy. Since IFNT stimulated CCL8 and CXCL10 expression in cultured PBLS, the increase of CCL8 and CXCL10 might be pregnancy-dependent events. The expression of both CCL8 and CXCL10 in PBLs was stimulated by CCL16 as well as IFNT, suggesting a chemokine interaction that at least includes CCL8, CXCL10 and CCL16, and may play a role in regulating maternal recognition in cows.
\end{abstract}

Keywords: CCL8, Cow, CXCL10, Leukocytes, Pregnancy

\section{Background}

Diagnosis of early pregnancy is important to improve reproductive efficiency and bring economic benefits to livestock production [1]. The ability to detect pregnancy early would help to shorten interbreeding intervals, since nonpregnant cows can be given an opportunity to synchronize their estrous cycle and be artificially inseminated prior to

\footnotetext{
* Correspondence: sakumoto@affrc.go.jp

'Division of Animal Breeding and Reproduction Research, Institute of Livestock and Grassland Science, National Agriculture and Food Research Organization (NARO), Ibaraki 305-0901, Japan

Full list of author information is available at the end of the article
}

the next ovulation. Over the past few decades, various direct or indirect methods to diagnose pregnancy have emerged such as rectal palpation [2], ultrasonography [3], serum progesterone concentration [4], early pregnancy factor [5], and pregnancy-specific protein B (PSPB: known as pregnancy-associated glycoprotein-1) [6, 7]. Although these methods to diagnose pregnancy have individual merits, they can only be adopted at the earliest $4 \mathrm{wk}$ after artificial insemination (AI).

Recent studies have shown that interferon-t (IFNT), which is a known key maternal recognition factor, 
stimulates the expression of interferon-stimulated genes (ISGs), such as interferon-stimulated protein $15 \mathrm{kDa}$ (ISG15), myxovirus-resistance (MX) proteins 1 and 2, and 2 ' -5 ' -oligoadenylate synthetase 1 (OAS1) in peripheral blood leukocytes (PBLs) in cows [8-14]. These findings provide a possibility to diagnose pregnancy within 3 wks after AI, but have shown variable effectiveness. For example, ISG15 mRNA levels in PBLs on $18 \mathrm{~d}$ after AI revealed poor accuracy as an early pregnant marker in dairy cows, although accuracy increased from 17 to $25 \mathrm{~d}$ [8]. MX2 mRNA levels in PBLs from 0 to $18 \mathrm{~d}$ after AI did not change considerably in dairy cows [9], whereas OAS1 mRNA levels were successfully used to assess pregnancy on $18 \mathrm{~d}$ in heifers but not in cows [10]. Furthermore, a combination of gene expression of ISGs in PBLs and color Doppler ultrasonography of the corpus luteum on $20 \mathrm{~d}$ after AI in beef cattle was used as a feasible method to diagnose pregnancy with high accuracy [14].

Our recent study demonstrated that the expression of CCL8 (also known as MCP-2) and CXCL10 (also known as IP-10) mRNA was higher in the bovine endometrium on 15 and $18 \mathrm{~d}$ of pregnancy than in the non-pregnant stage [15]. Furthermore, the expression of both CCL8 and CXCL1O increased after stimulation with IFNT using an in vitro endometrial culture system [15]. We subsequently hypothesized that the expression of CCL8 and CXCL1O would increase in PBLs during early stages of pregnancy, and that it was possible to use both chemokines as biomarkers for early pregnancy diagnosis in cows. In the present study, we therefore examined changes in the expression of CCL8 and CXCL10 in PBLs obtained from cows on 14 to $18 \mathrm{~d}$ after AI in three conditions: pregnancy, early embryonic mortality (EEM) or late embryonic mortality (LEM). The effects of IFNT and CCL16, which stimulated ISGs mRNA expression in the bovine endometrium [15], on the expression of CCL8 and CXCL1O by monocytes, granulocytes and lymphocytes fractionated by flow cytometry were also studied.

\section{Methods}

\section{Collection of bovine peripheral blood}

Fifteen normal cyclic Japanese Black cows (age: 3-13 yr, parity: 1-9) were used in this study. To detect estrus, cows were observed daily for standing behavior. AI was performed on the day of estrus using frozen semen from Japanese black bulls. The day of AI was designated as $0 \mathrm{~d}$, and blood was collected from the jugular vein in heparin sodium-containing vacutainers on 14, 15, 16, 17 and $18 \mathrm{~d}$ after AI. Half of the blood samples were centrifuged at $1,200 \times g$ for $30 \mathrm{~min}$, and plasma was separated to evaluate protein concentration. The remaining of blood and plasma samples were stored at $-80{ }^{\circ} \mathrm{C}$. The data were collected separately for the pregnant (confirmed parturition; $n=5$ ),
EEM (return of estrus during 19-21 d; $n=5$ ) and LEM (return of estrus during $25-35 \mathrm{~d} ; n=5$ ) cows, according to the criteria of a previous study [16].

\section{Real-time PCR}

Total RNA was isolated from whole blood using a commercial RNA extraction kit (NucleoSpin RNA Blood, \#740200, Macherey-Nagel GmBH\&Co. KG, Büren, Germany) in accordance with the manufacturer's instructions. The NucleoSpin RNA blood kits are recommended for the isolation of RNA from fresh and frozen whole blood. All RNA samples were quantified by spectrophotometry (\#ND-1000, Nanodrop Technology Inc., Wilmington, DE, USA) and the purification of RNA with A260/A280 ratio was between 2.0 and 2.2. Complementary DNA was synthesized from 500 ng of total RNA using a QuantiTect Reverse Transcription kit (\#205314, Qiagen, Hilden, Germany). Gene expression was measured by real-time PCR using an Mx3000P Real Time PCR analyzing system (Agilent Technologies, Santa Clara, CA, USA) and a QuantiFast SYBR Green PCR kit (\#204054, Qiagen) as previously described [17]. The primers encoding the bovine sequences were chosen using an online software package (http://primer3.ut.ee/) and synthesized as listed in Table 1. Primer length (18-21 bp) and GC content of each primer (50\% to 60\%) were selected to avoid primer dimer formation. PCR was performed under the following conditions: (first step) $95{ }^{\circ} \mathrm{C}$ for $5 \mathrm{~min} ; 45$ cycles of $95{ }^{\circ} \mathrm{C}$ for $15 \mathrm{~s}, 60{ }^{\circ} \mathrm{C}$ for $30 \mathrm{~s}$ and (second step) $95{ }^{\circ} \mathrm{C}$ for $60 \mathrm{~s}$; then $60{ }^{\circ} \mathrm{C}$ for $30 \mathrm{~s}$. The reaction was then held at $25^{\circ} \mathrm{C}$. After each PCR cycle, melting curves were obtained to ensure single product amplification. Standard curves for each gene were generated by serially diluting plasmids containing cDNA of each individual gene to quantify mRNA concentration. The obtained data were normalized on the basis of GAPDH mRNA content. To exclude any contaminating genomic DNA, all experiments included controls that lacked the reverse transcription enzyme. As a negative control, water was used instead of RNA for PCR to exclude any contamination from buffers and tubes.

\section{Flowcytometric collection of monocytes, granulocytes and lymphocytes}

Flowcytometric separation of PBLs was carried out as previously described [13] with a slight modification. Blood samples were collected by the jugular vein from five Japanese Black cows on 10-12 d of the estrous cycle. After blood was collected, $8 \mathrm{~mL}$ of whole blood was carefully layered onto $4 \mathrm{~mL}$ of Histopaque-1119 (1.119 g/mL density, Sigma-Aldrich Co., LLC, St. Louis, MO, USA) and centrifuged at $780 \times g$ for $30 \mathrm{~min}$ at room temperature. The serum fraction was removed. Two milliliters of the upper part of the whole blood cell pellet 
Table 1 Primers used in real-time PCR

\begin{tabular}{|c|c|c|c|c|}
\hline Genes & & Sequence $\left(5^{\prime} \rightarrow 3^{\prime}\right)$ & GenBank accession number & Size, bp \\
\hline \multirow[t]{2}{*}{ CCL8 } & Forward & AACATGAAGGTCTCCGCTGG & NM_174007 & 108 \\
\hline & Reverse & GCAGCAGGTGATTGGGGTAG & & \\
\hline \multirow[t]{2}{*}{ CXCL10 } & Forward & CTCGAACACGGAAAGAGGCA & NM_001046551 & 117 \\
\hline & Reverse & TCCACGGACAATTAGGGCTT & & \\
\hline \multirow[t]{2}{*}{ ISG15 } & Forward & GCAGACCAGTTCTGGCTGTCT & NM_174366 & 58 \\
\hline & Reverse & CCAGCGGGTGCTCATCAT & & \\
\hline \multirow[t]{2}{*}{$M \times 1$} & Forward & GAGGTGGACCCCCAAGGA & NM_173940 & 58 \\
\hline & Reverse & CCACCAGATCGGGCTITGT & & \\
\hline \multirow[t]{2}{*}{ MX2 } & Forward & GGGCAGCGGAATCATCAC & NM_173941 & 55 \\
\hline & Reverse & CTCCCGCTITGTCAGTITCAG & & \\
\hline \multirow[t]{2}{*}{ GAPDH } & Forward & ACCCAGAAGACTGTGGATGG & U85062 & 158 \\
\hline & Reverse & CAACAGACACGTTGGGAGTG & & \\
\hline
\end{tabular}

fraction, which included red cells, was centrifuged at $1,200 \times g$ for $5 \mathrm{~min}$ at room temperature. After removing the supernatant, the blood cell fraction was suspended in pre-warmed $\left(37{ }^{\circ} \mathrm{C}\right)$ lysing buffer $(155 \mathrm{mmol} / \mathrm{L}$ $\mathrm{NH}_{4} \mathrm{Cl}, 10 \mathrm{mmol} / \mathrm{L} \mathrm{KHCO}_{3}$, and $1 \mathrm{mmol} / \mathrm{L}$ EDTA), and immediately diluted with sorting buffer composed of Hank's balanced salt solution containing $2 \%$ fetal bovine serum and $10 \mathrm{mmol} / \mathrm{L}$ 4-(2-hydroxyethyl)-1-piperazineethanesulfonic acid. After washing with sorting buffer, cells were re-suspended in cold sorting buffer containing $2 \mu \mathrm{g} / \mathrm{mL}$ propidium iodide (PI) and sorted into three populations (monocytes, granulocytes and lymphocytes) using a MoFlo Astrios cell sorter (Beckman Coulter, Carlsbad, CA, USA). Cell debris and platelet populations were removed using several intrinsic fluorescent parameters and cells were then sorted using the 488-513/59 parameter versus side scatter (SSC) or the 355-448/59 parameter. Each cell population was confirmed by cell lineage-specific antibodies: anti-granulocyte antibody (\#MM20A, VMRD Inc., Pullman, WA, USA), anti-bovine monocyte antibody (\#BAQ151, VMRD), or anti-CD3 antibody (\#MM1A, VMRD).

\section{Culture of PBLs}

The monocytes, granulocytes and lymphocytes were placed separately in culture medium (DMEM/Ham's F-12; 1:1 (v/v); \#D8900, Sigma-Aldrich) supplemented with 10\% $(v / v)$ calf serum (\#C6278, Sigma-Aldrich), 20 IU/mL penicillin, $20 \mu \mathrm{g} / \mathrm{mL}$ streptomycin, and $0.05 \mu \mathrm{g} / \mathrm{mL}$ amphotericin B (\#516104, EMD Millipore Corp. Billerica, MA, USA) and cultured at $37.5{ }^{\circ} \mathrm{C}$ in a humidified atmosphere of $5 \%$ $\mathrm{CO}_{2}$ in air $\left(2.5 \times 10^{4}\right.$ cells $/ 200 \mu \mathrm{L} /$ well in a 96-well culture plate, Nunc-Thermo Fisher Scientific). Cultured leukocytes were further incubated in this medium with recombinant proteins as follows: bovine IFNT $(100 \mathrm{ng} / \mathrm{mL}$ : $1.1 \times 10^{5}$ units $/ \mathrm{mg}$, generated from HEK293 cells as described previously [18]) or recombinant human CCL16
(100 ng/mL: \#TP723266, OriGene Technologies, Inc., Rockville, MD, USA). After incubation for $18 \mathrm{~h}$, the leukocytes and supernatant were collected separately and stored at $-80^{\circ} \mathrm{C}$ until use. Total RNA from PBLs was extracted using an RNeasy Micro Kit (\#74004, QIAGEN) in accordance with the manufacturer's protocols, and used for the subsequent gene expression analysis.

\section{Statistical analyses}

The expression ratio of each gene to GAPDH mRNA was calculated to adjust for variations in the PCR reaction. The experimental data for real-time PCR are presented as the mean \pm SEM. The difference of mRNA expression in the PBLs between $14 \mathrm{~d}$ and 15, 16, 17, $18 \mathrm{~d}$ in each group (pregnant, EEM and LEM) was analyzed using one-way ANOVA for repeated measures with Dunnett's Multiple Comparison post hoc test with the KaleidaGraph 3.6 (Synergy Software, Reading, PA, USA) software package. In PBL culture experiments, the experimental data for real-time PCR were shown as percentage of the control value $(n=5)$. The differences between mRNA expression in the cultured PBLs between the control group and the treated group were analyzed using one-way ANOVA with Tukey-Kramer multiple comparison test. A $P$-value $<0.05$ was considered statistically significant.

\section{Results}

CCL8 and CXCL1O transcripts in PBLs gradually increased from 14 to $18 \mathrm{~d}$ of pregnant cows and significant differences were observed on $18 \mathrm{~d}$ (Figs. 1 and 2; $P<0.05$ ), whereas no significant changes were observed both in EEM and LEM cows. ISG15, MX1 and MX2 mRNA expression in PBLs was significantly higher on $18 \mathrm{~d}$ than $14 \mathrm{~d}$ of pregnant cows as well as in LEM cows (Figs. 3, 4, and 5; $P<0.05)$, but no changes were observed in EEM cows.

The addition of IFNT and CCL16 stimulated CCL8, CXCL10, ISG15, MX1 and MX2 mRNA expression in 

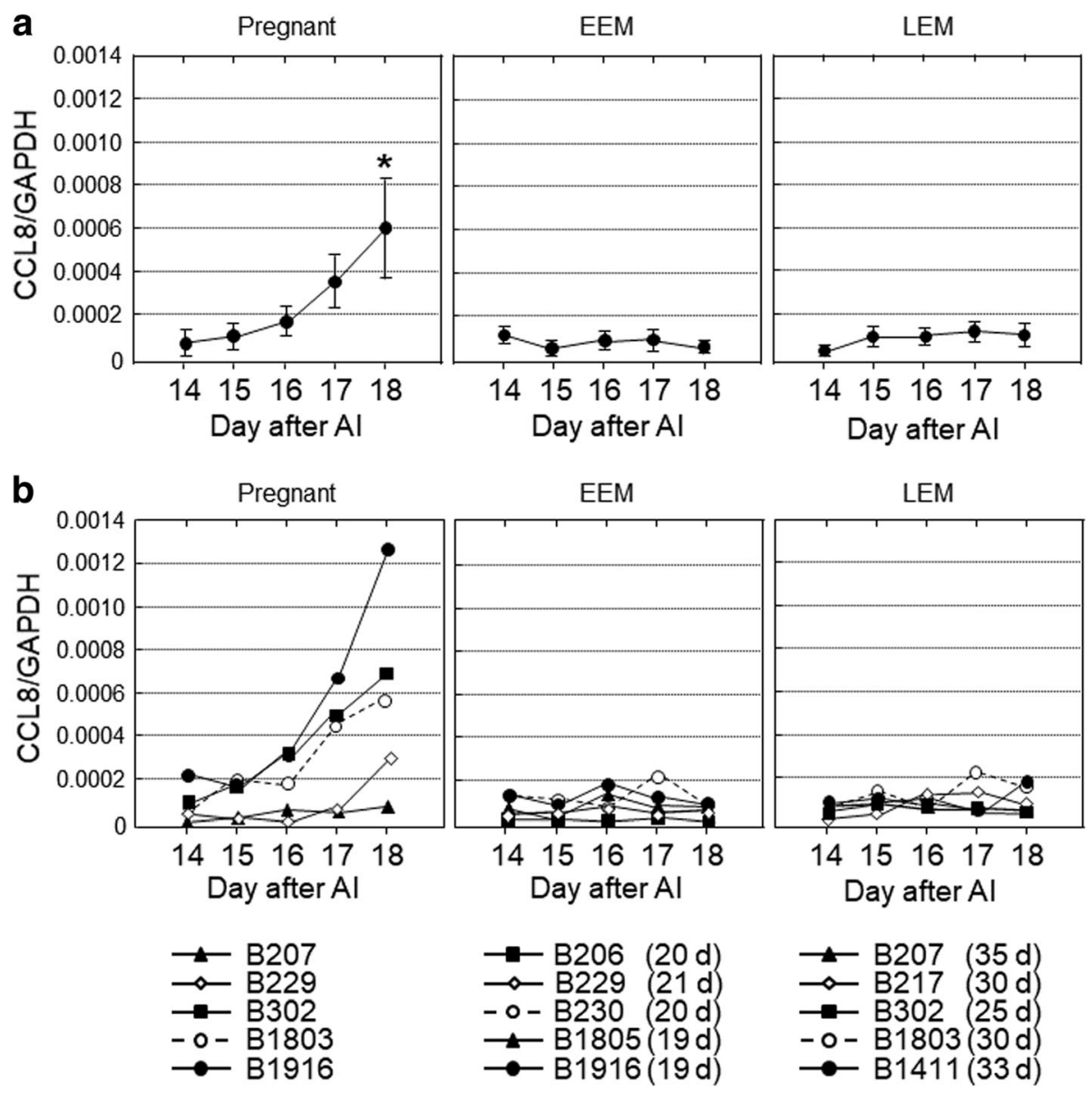

Fig. 1 The gene expression levels of CCL8 in peripheral blood leukocytes obtained from cows on 14, 15, 16, 17 and $18 \mathrm{~d}$ after artificial insemination (Al). Based on the day of return of estrus, the cows were divided into three groups, pregnant $(n=5)$, early embryonic mortality $(E E M ; n=5)$ and late embryonic mortality $(\operatorname{LEM} ; n=5)$. a Data are means \pm SEM of five cows and are expressed as relative ratios of the mRNAs to $G A P D H$. Values significantly different from the value on $14 \mathrm{~d}$ after Al are shown with an asterisk (*P<0.05). $\mathbf{b}$ Each line represents the data for individual cows, and the figure in parentheses indicates the day of the return of estrus in EEM and LEM cows

cultured monocytes and granulocytes (Fig. 6; $P<0.05$ ). The stimulatory effect of IFNT on ISG15 mRNA expression was higher than CCL16 in monocytes (Fig. 6c; $P<0.05$ ). In lymphocytes, IFNT stimulated CCL8, CXCL10, ISG15, $M X 1$ and $M X 2$ mRNA expression (Fig. 6; $P<0.05$ ). CCL16 stimulated CXCL10, ISG15, MX1 and MX2 mRNA (Fig. 6b-e; $P<0.05$ ), but it did not stimulate significantly on CCL8 mRNA expression (Fig. 6a).

\section{Discussion}

This study demonstrated that the expression of CCL8 and CXCL1O genes in PBLs increased on $18 \mathrm{~d}$ in pregnant cows, whereas this up-regulation was not observed in non-pregnant cows. In addition, the expression of both CCL8 and CXCL1O mRNA in cultured PBLs was stimulated by IFNT. Our previous study shown that the expression of six chemokine genes, including CCL8 and CXCL10, was higher in the bovine endometrium on 15 and $18 \mathrm{~d}$ of pregnancy than in the non-pregnant stage, and that CCL8 and CXCL1O mRNAs increased after stimulation with IFNT using an in vitro endometrial culture system [15]. These observations support the hypothesis that up-regulation of CCL8 and CXCL1O in bovine PBLs is a pregnancy-dependent event.

Chemokines were first discovered as mediators of migration of immune cells to sites of inflammation and injury, and now they play multiple roles in organ development, angiogenesis, and tumorigenesis [19]. Chemokines have also been implicated in a number of reproductive events, such as ovulation, menstruation, embryo implantation, parturition and endometriosis [20, 21]. Peripheral blood cells are mainly composed of erythrocytes, platelets and leukocytes. Leukocytes are further divided into monocytes (macrophages and dendritic cells), granulocytes (neutrophils, eosinophils and basophils) and lymphocytes (T-cells, B-cells and natural killer [NK] cells). CCL8 is produced by monocytes and macrophages, and mainly 

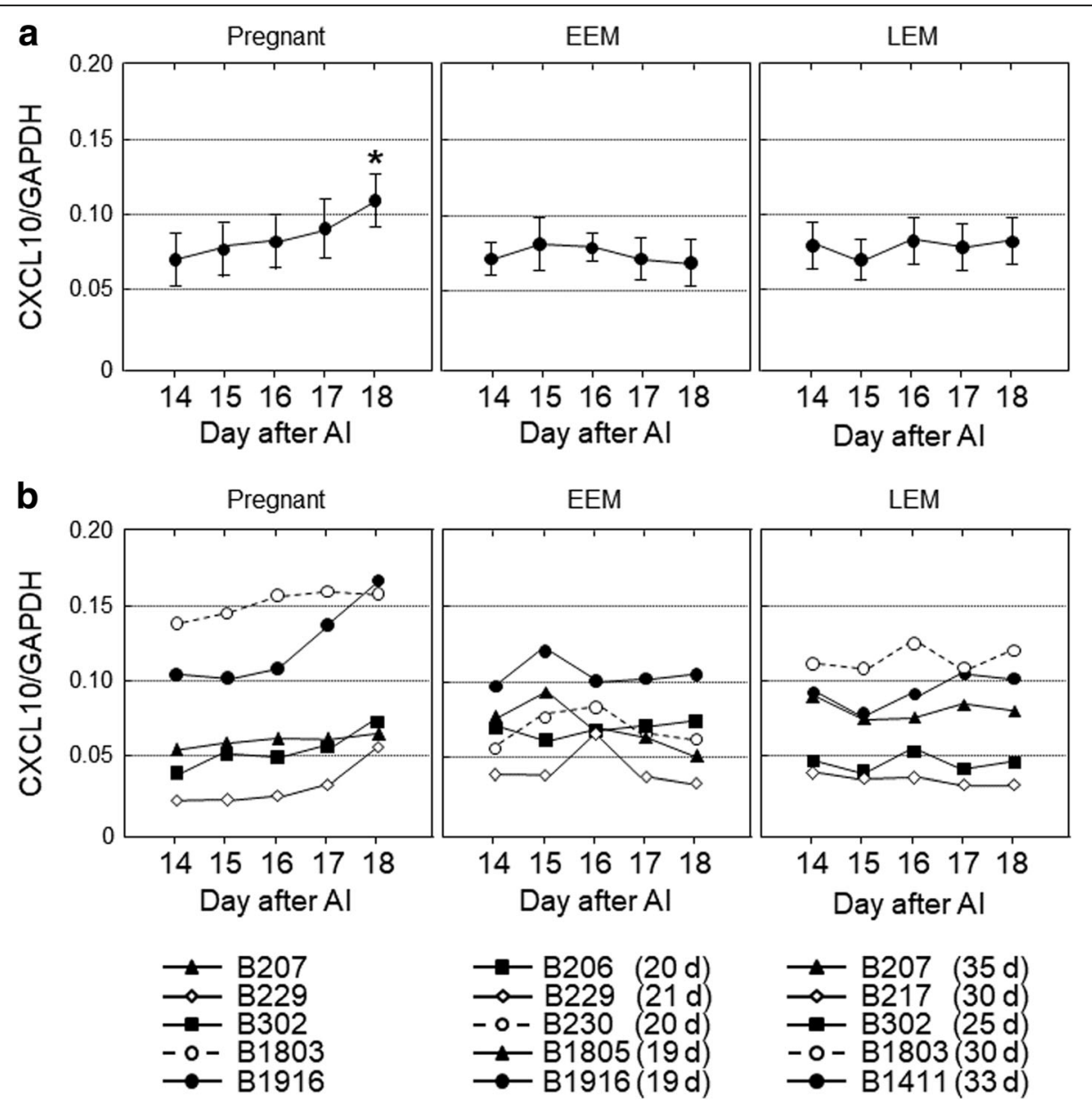

Fig. 2 The gene expression levels of CXCL10 in peripheral blood leukocytes obtained from cows on 14,15,16,17 and $18 \mathrm{~d}$ after artificial insemination (Al). Based on the day of return of estrus, the cows were divided into three groups, pregnant $(n=5)$, early embryonic mortality $(E E M ; n=5)$ and late embryonic mortality $(\operatorname{LEM} ; n=5)$. a Data are means \pm SEM of five cows and are expressed as relative ratios of the mRNAs to GAPDH. Values significantly different from the value on $14 \mathrm{~d}$ after $\mathrm{Al}$ are shown with an asterisk $\left({ }^{*} P<0.05\right)$. $\mathbf{b}$ Each line represents the data for individual cows, and the figure in parentheses indicates the day of the return of estrus in EEM and LEM cows

acts through its receptors (CCR1, CCR2 and CCR3) on monocytes, eosinophils and T lymphocytes [22]. Eosinophils produce CCL8, and the number of eosinophils increases within the uterus during early pregnancy in ewes [23]. The CCL8 transcript has also been identified in the bovine endometrium and increased in cows during an early stage of pregnancy $[15,24]$. Messenger RNA expression of CCL8 receptors are detected in the bovine endometrium during both the estrous cycle and pregnancy, and their proteins are localized in the epithelial and glandular epithelial cells of bovine endometrium [15]. Although CCL8 has been reported to decrease both the expression of cyclooxygenase (COX)-2 and oxytocin receptors in cultured bovine endometrial tissues [15], the physiological importance of CCL8 during maternal recognition still needs to be clarified.

In contrast to CCL8, information on CXCL10 has been well documented [20]. CXCL10 inhibits endothelial cell proliferation, chemotaxis, activation of Th1 cells, NK cells and macrophages. CXCL10 is also known to be induced by interferons and acts in response to several angiogenic factors, including other CXC chemokines and growth factors [25]. CXCL10 is found in monocytes that are localized in the subepithelial stroma of the ovine endometrium, and its expression is stimulated by IFNT and interferon- $\gamma$ [26]. The level of CXCL10 expression in the endometrium is higher during pregnancy than in the non-pregnant stage in goats [27] and cows [15]. In addition, CXCL10 induces the recruitment of numerous leukocytes in the ovine uterus and enhances the ability of trophoblasts to attach to endometrium [28]. CXCL10 also induces caprine trophoblast adhesion [29] and chemotaxis in human trophoblast cell lines [30]. CXCL10 binds to both CXCR3A and CXCR3B, which are two alternatively spliced forms. CXCR3A is the major chemokine receptor found on $\mathrm{T}$ lymphocytes and 

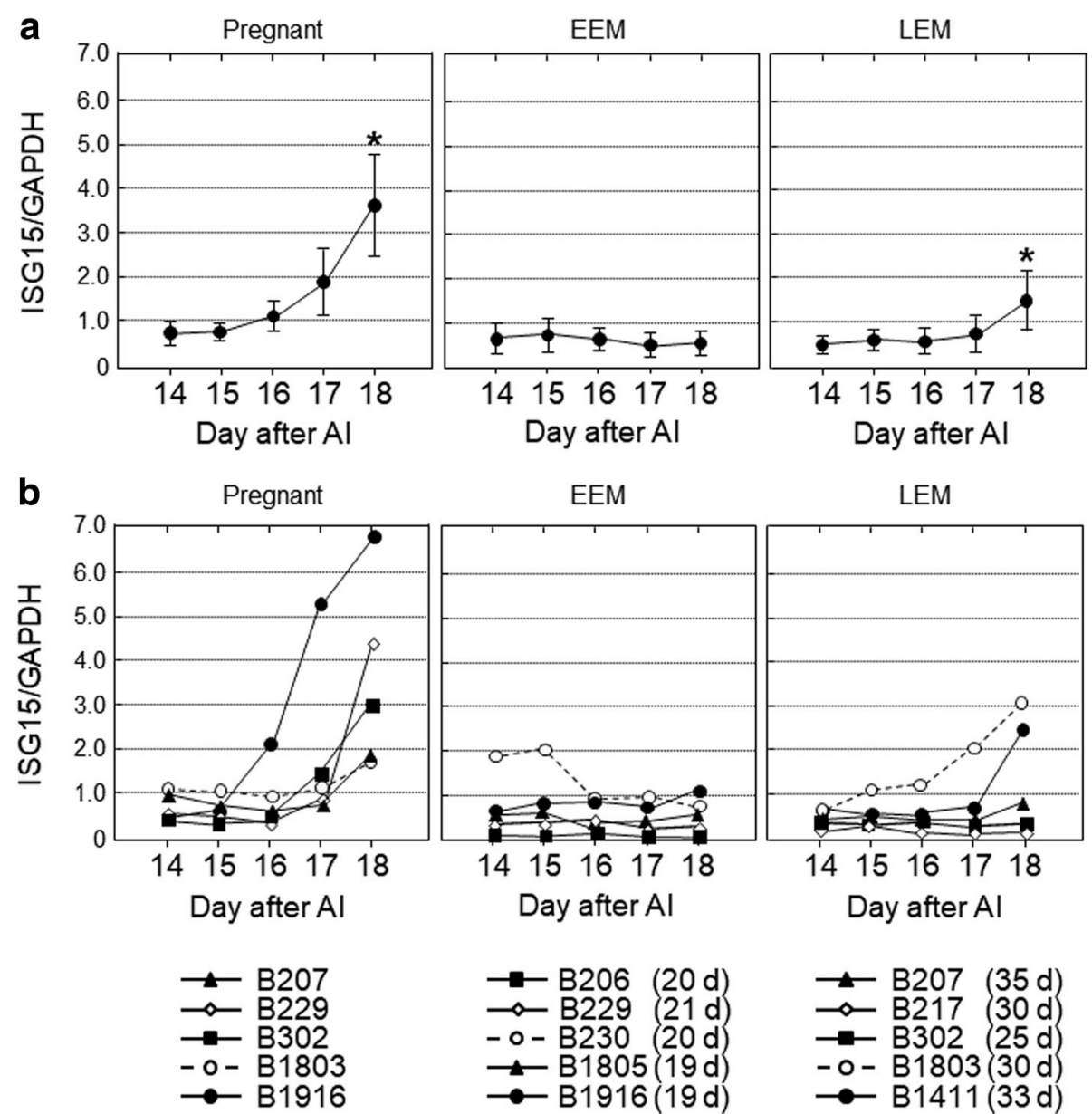

Fig. 3 The gene expression levels of ISG15 in peripheral blood leukocytes obtained from cows on 14, 15, 16, 17 and $18 \mathrm{~d}$ after artificial insemination (Al). Based on the day of return of estrus, the cows were divided into three groups, pregnant $(n=5)$, early embryonic mortality $(E E M ; n=5)$ and late embryonic mortality $(\operatorname{LEM} ; n=5)$. a Data are means \pm SEM of five cows and are expressed as relative ratios of the $m R N A s$ to $G A P D H$. Values significantly different from the value on $14 \mathrm{~d}$ after $\mathrm{Al}$ are shown with an asterisk $\left({ }^{*} P<0.05\right)$. $\mathbf{b}$ Each line represents the data for individual cows, and the figure in parentheses indicates the day of the return of estrus in EEM and LEM cows

NK cells, and plays a critical role in the development of anti-tumor immunity and inhibits angiogenesis, which is relevant to a variety of tumors [31], whereas CXCR3B mediates the angiostatic activity of CXCL10 on human microvascular endothelial cells [32]. Thus, IFNT-stimulated CXCL10 production in PBLs may play a variety of roles in many cells including immune cells, endothelial cells, endometrial cells and the conceptus at the time of maternal recognition in cows.

Our previous study demonstrated that CCL16 mRNA expression was high in the endometrium on $15 \mathrm{~d}$, but not on $18 \mathrm{~d}$, of pregnant cows than in non-pregnant cows. Moreover, since CCL16 stimulated the expression of ISG15 and MX1 in cultured endometrial tissues [15], we prospected that CCL16 might affect the expression of chemokines or ISGs mRNA in PBLs. In this study, CCL16 stimulated the expression of CCL8, CXCL10 and ISG genes in cultured PBLs. CCL16 increases the antigen presentation of macrophages, enhances T-cell cytotoxicity and stimulates the production of a number of inflammatory-type cytokines (IL-1 $\beta$, TNF, IL-12) [33]. CCL16 and its receptors (CCR1 and CCR2) were identified in the preterm placenta [34] and bovine endometrium [15]. CCL16 induces endothelial cell motility, which is pivotal in vessel formation by stimulating the release of proinflammatory and proangiogenic chemokines [35, 36]. Although a further study is needed to clarify the role of CCL16 in cows, CCL16 may influence angiogenesis and anti-viral activity by up-regulating CCL8 and CXCL10 as well as the expression of ISGs at the time of maternal recognition.

The early diagnosis of pregnancy is useful by shortening interbreeding intervals, and subsequently brings economic benefits for livestock production. Transrectal ultrasonography is commonly used to diagnose pregnancy by visualizing a viable embryo between 28 and $35 \mathrm{~d}$ post-AI [1]. 

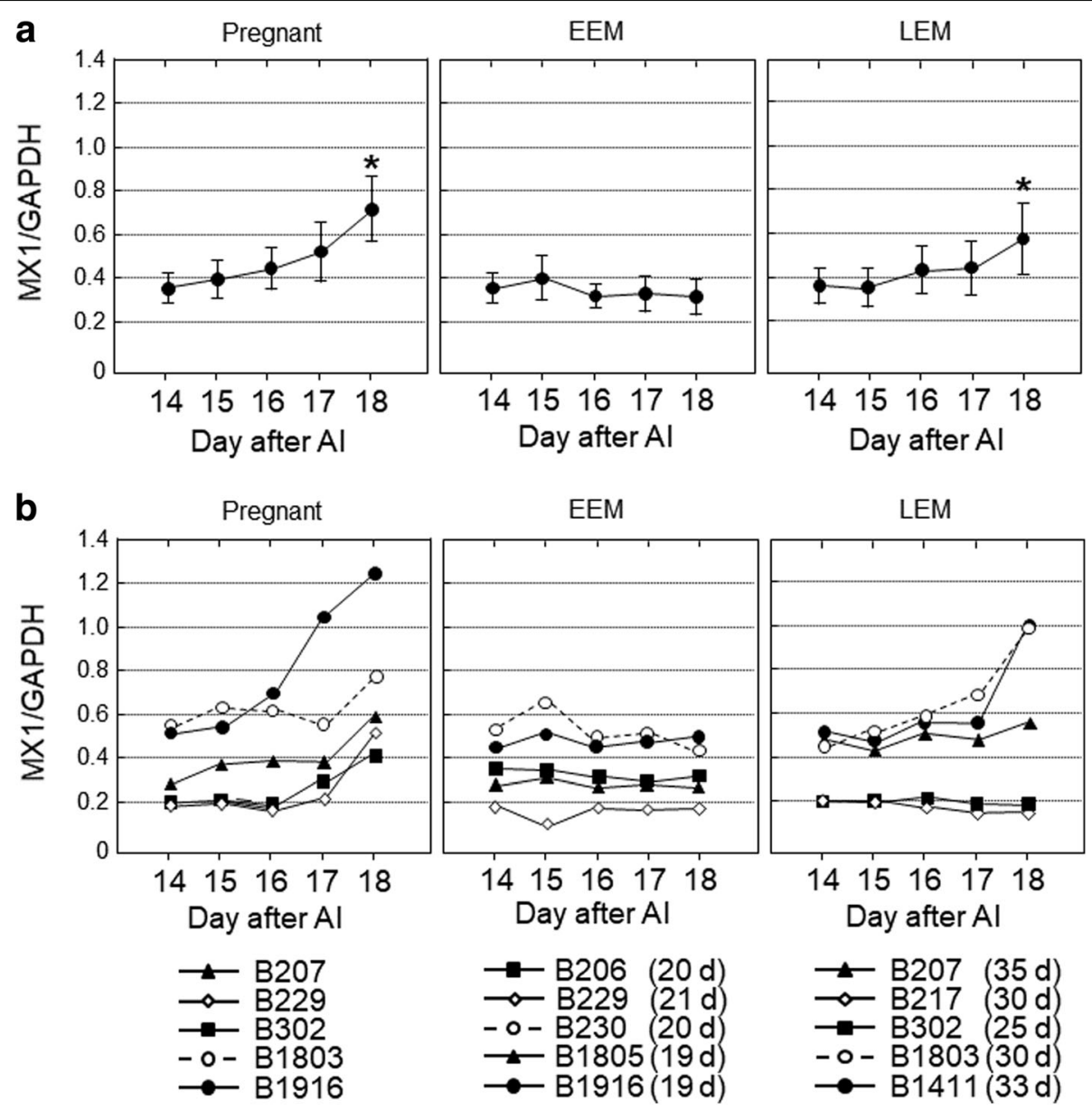

Fig. 4 The gene expression levels of $M X 1$ in peripheral blood leukocytes obtained from cows on 14, 15, 16, 17 and $18 \mathrm{~d}$ after artificial insemination (AI). Based on the day of return of estrus, the cows were divided into three groups, pregnant $(n=5)$, early embryonic mortality $(E E M ; n=5)$ and late embryonic mortality $(\operatorname{LEM} ; n=5)$. a Data are means \pm SEM of five cows and are expressed as relative ratios of the mRNAs to $G A P D H$. Values significantly different from the value on $14 \mathrm{~d}$ after Al are shown with an asterisk $(* P<0.05)$. $\mathbf{b}$ Each line represents the data for individual cows, and the figure in parentheses indicates the day of the return of estrus in EEM and LEM cows

Although this method is useful because of its simplicity, earlier diagnostic methods that can be adopted within three or 4 wk are desired. In this study, cows in which estrus returned between 19 and $21 \mathrm{~d}$ were classified as EEM, and those between 30 and $35 \mathrm{~d}$ as LEM, according to a previous study in which cows were classified as EEM when estrus returned before $24 \mathrm{~d}$, and as LEM when it returned between 24 and $50 \mathrm{~d}$ [16]. Since we could not confirm a presence or absence of conceptus by an ultrasound imaging until $30 \mathrm{~d}$ after AI, EEM and LEM may not represent early embryonic loss or fertilization failure in fact. The expression of CCL8 and CXCL10 genes was high in PBLs on $18 \mathrm{~d}$ of pregnant cows, but not in EEM and LEM cows, suggesting that the gene expression profiles of CCL8 and CXCL10 may be helpful to estimate embryonic mortality or fertilization failure in cows.

In this study, the expression level of ISGs (ISG15, MX1 and MX2) in the PBLs was higher on $18 \mathrm{~d}$ than 14 $\mathrm{d}$ in LEM cows as well as pregnant cows, suggesting that the embryo might still be alive on $18 \mathrm{~d}$ in LEM cows. However, the expression of CCL 8 and CXCL10 mRNA did not change in LEM cows. Chemokine production is regulated by growth factors and cytokines/chemokines $[25,26]$, and indeed the expression of CCL8 and CXCL1O mRNAs in cultured PBLs was stimulated by CCL16. These results allow us to hypothesize that up-regulation of chemokines and ISGs in early pregnant cows may in part be regulated by a different pathway. Although CCL16 was highly expressed in the endometrium on $15 \mathrm{~d}$ of pregnant cows than in non-pregnant cows, its expression was not stimulated by IFNT using an in vitro endometrial culture system [15], suggesting that pregnancy-dependent CCL16 upregulation occurs as an indirect action of IFNT. Further studies are needed to clarify the detailed mechanism of chemokine-IFNT interaction in bovine PBLs. 

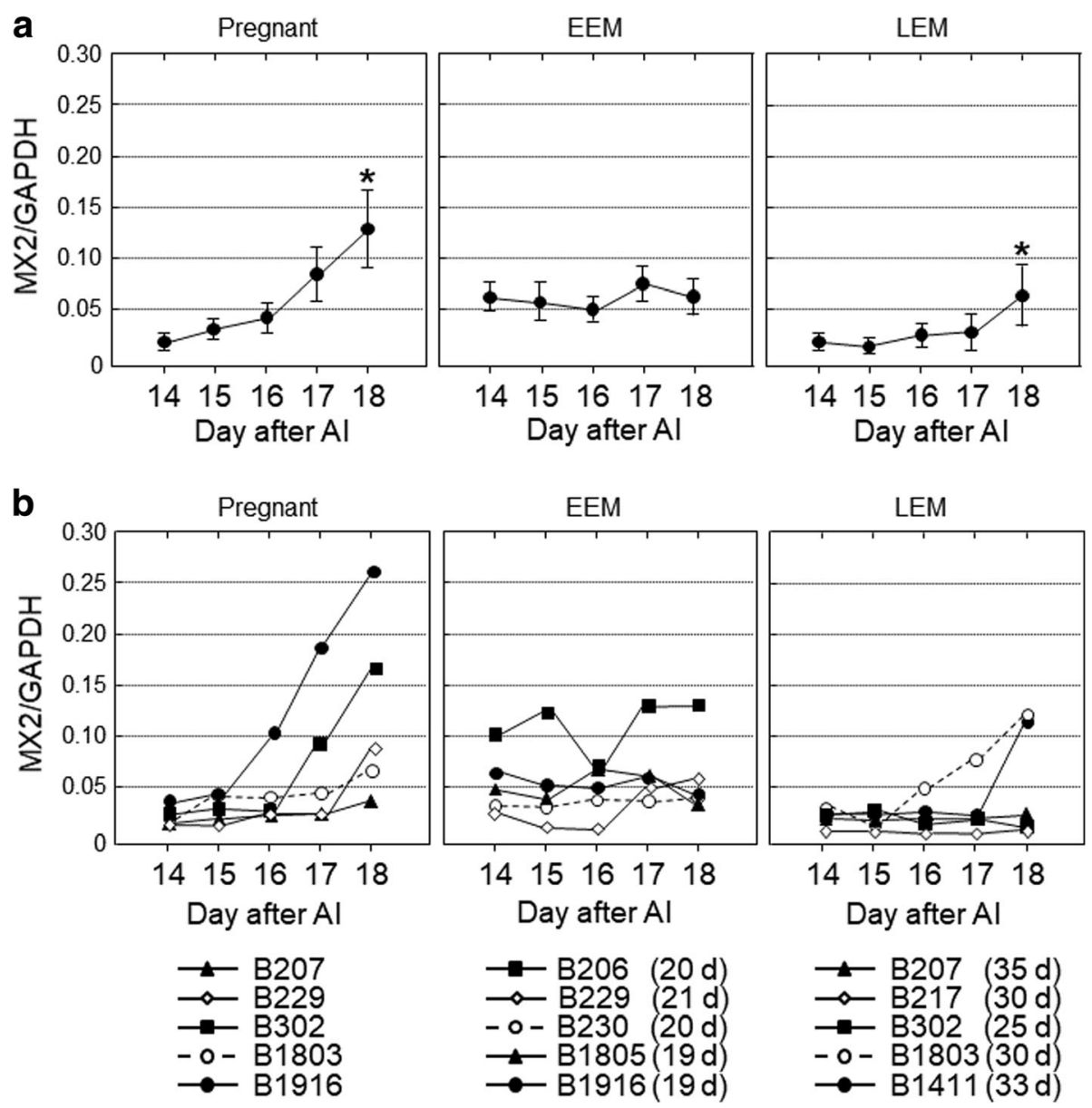

Fig. 5 The gene expression levels of MX2 in peripheral blood leukocytes obtained from cows on 14, 15, 16, 17 and $18 \mathrm{~d}$ after artificial insemination (Al). Based on the day of return of estrus, the cows were divided into three groups, pregnant $(n=5)$, early embryonic mortality $(E E M ; n=5)$ and late embryonic mortality $(\operatorname{LEM} ; n=5)$. a Data are means \pm SEM of five cows and are expressed as relative ratios of the mRNAs to GAPDH. Values significantly different from the value on $14 \mathrm{~d}$ after $\mathrm{Al}$ are shown with an asterisk $\left.{ }^{*} P<0.05\right)$. $\mathbf{b}$ Each line represents the data for individual cows, and the figure in parentheses indicates the day of the return of estrus in EEM and LEM cows

A previous study demonstrated that the expression of ISGs in the granulocyte fraction on $14 \mathrm{~d}$ of pregnancy was significantly higher than in the monocyte and lymphocyte fractions [13]. Hence, we believe that granulocytes would have more responsibility with IFNT than monocytes and lymphocytes. Unexpectedly, stimulatory effects of IFNT on ISG15 expression in the monocytes $(57,100 \%)$ were tended to be high relative to granulocytes $(10,943 \%)$ and lymphocytes $(32,192 \%)$ in our in vitro experiments. We could not determine an appropriate reason, but in vitro culture conditions may be the cause for these different results. Although we selected the dose of IFNT $(100 \mathrm{ng} / \mathrm{mL})$ and stimulation period (18 h) according to previous studies [15, 37-39], it has also been demonstrated that ISG15 mRNA expression was stimulated by IFNT at lower concentrations ( 0.1 and $1 \mathrm{ng} / \mathrm{mL})$ and a shorter period of stimulation $(4 \mathrm{~h})$ [40].
Furthermore, IFNT $(0.1 \mathrm{ng} / \mathrm{mL})$ for $4 \mathrm{~h}$ significantly induced the expression of ISG15 and OAS1 in granulocytes, but not in whole PBLs [11]. Therefore, stimulatory effects of IFNT on the expression of ISGs in cultured PBLs might have been masked after $18 \mathrm{~h}$ incubation in our in vitro study. On the other hand, we also attempted to measure CCL8, CXCL10, ISG15, MX1 and MX2 proteins using commercial available ELISA kits, since endocrinological early pregnancy diagnosis seems to be a more convenient method than genetic diagnosis. However, the concentration of CCL8, CXCL10 and ISGs in the plasma and conditioned media of cultured PBLs was not detectable and thus it was not possible to evaluate any changes between pregnant and non-pregnant cows. Hence, a very highly sensitive ELISA kit or concentration of target proteins in serum would be needed to apply endocrinological diagnosis in the future. 


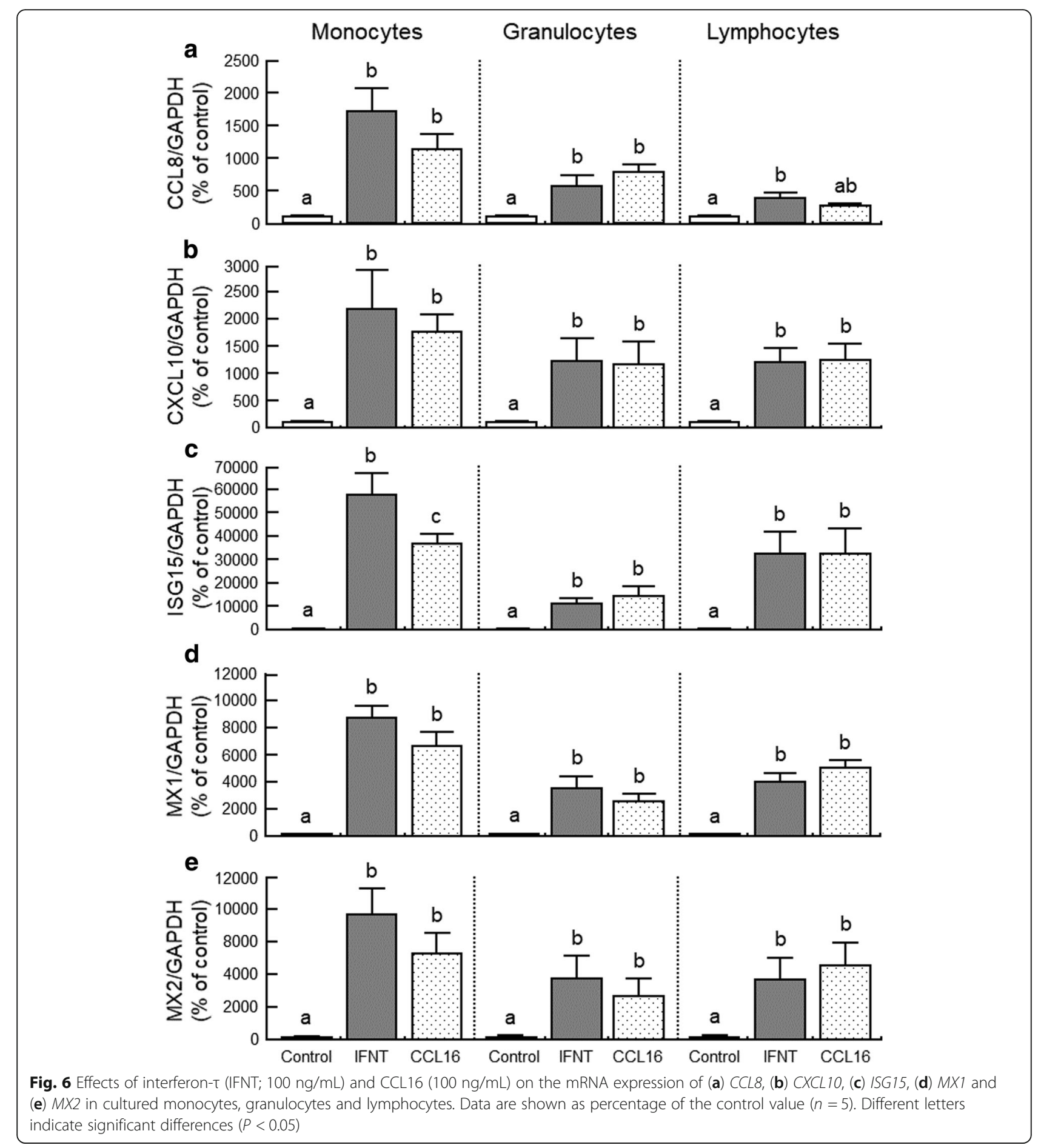

\section{Conclusions}

The present study demonstrated that the expression of CCL8 and CXCL1O genes in PBLs increased from 14 to $18 \mathrm{~d}$ of pregnant cows, whereas no significant changes were observed in EEM and LEM cows. Since IFNT stimulated CCL8 and CXCL1O expression in cultured PBLs, the increase of CCL8 and CXCL1O might be pregnancy-dependent events. Moreover, the expression of both CCL8 and CXCL10 in cultured PBLs was stimulated by CCL16 as well as IFNT, suggesting that chemokines, including CCL8, CXCL10 and CCL16, may play some roles at the time of maternal recognition.

\section{Abbreviations}

Al: Artificial insemination; EEM: Early embryonic mortality; ELISA: Enzymelinked immune solvent assay; IFNT: Interferon-т; IL: Interleukin;

ISGs: Interferon-stimulated genes; LEM: Late embryonic mortality; 
MX: Myxovirus-resistance gene; OAS1: 2'-5'-oligoadenylate synthetase 1; PBLS: Peripheral blood leukocytes; TNF: Tumor necrosis factor-a

\section{Acknowledgements}

The authors thank the staff of the Livestock Operations Unit 1, Tsukuba Technical Support Center, and Operations Unit 2, Technical Support Center Tohoku Agricultural Research Center, NARO for their skilled technical assistance.

\section{Funding}

This research was supported by Grants-in-Aid for the Research Program on Innovative Technologies for Animal Breeding, Reproduction, and Vaccine Development (REP1001) from the Ministry of Agriculture, Forestry and Fisheries of Japan. RS was supported by JSPS KAKENHI Grant Number 17 K08056.

\section{Availability of data and materials}

All data generated or analyzed during this study available from the corresponding authors on reasonable request.

\section{Authors' contributions}

RS participated in the design of the study, carried out all experiments and drafted the manuscript. KI and $\mathrm{KGH}$ collected blood samples from cows. SF and $\mathrm{KH}$ carried out quantitative real-time PCR. MH participated in the design of the study. TF carried out flowcytometric analysis. All authors read and approved the final manuscript.

\section{Ethics approval}

All procedures for animal experiments were carried out in accordance with guidelines approved by the Animal Ethics Committee of the National Institute of Agrobiological Sciences (approval number: H18-036-03) and Tohoku Agricultural Research Center, NARO (approval numbers: 25-7 and 26-11) for the use of animals.

\section{Competing interests}

The authors declare that they have no competing interests.

\section{Author details}

'Division of Animal Breeding and Reproduction Research, Institute of Livestock and Grassland Science, National Agriculture and Food Research Organization (NARO), Ibaraki 305-0901, Japan. Division of Livestock and Forage Research, Tohoku Agricultural Research Center, NARO, Morioka 020-0198, Japan. ${ }^{3}$ Division of Animal Sciences, Institute of Agrobiological Sciences, NARO, Ibaraki 305-8602, Japan.

\section{Received: 7 December 2017 Accepted: 14 May 2018}

\section{Published online: 20 June 2018}

\section{References}

1. Balhara AK, Gupta M, Singh S, Mohanty AK, Singh I. Early pregnancy diagnosis in bovines: current status and future directions. Sci World J. 2013; 2013:958540. https://doi.org/10.1155/2013/958540.

2. Franco OJ, Drost M, Thatcher MJ, Shille VM, Thatcher WW. Fetal survival in the cow after pregnancy diagnosis by palpation per rectum. Theriogenology. 1987;27:631-44.

3. Fricke PM. Scanning the future-ultrasonography as a reproductive management tool for dairy cattle. J Dairy Sci. 2002;85:1918-26.

4. Shemesh M, Ayalon N, Lindner HR. Early pregnancy diagnosis based upon plasma progesterone levels in the cow and ewe. J Anim Sci. 1973:36:726-9.

5. Cordoba MC, Sartori R, Fricke PM. Assessment of a commercially available early conception factor (ECF) test for determining pregnancy status of dairy cattle. J Dairy Sci. 2001;84:1884-9.

6. Zoli AP, Guilbault LA, Delahaut P, Ortiz WB, Beckers JF. Radioimmunoassay of a bovine pregnancy-associated glycoprotein in serum: its application for pregnancy diagnosis. Biol Reprod. 1992;46:83-92.

7. Kiracofe GH, Wright JM, Schalles RR, Ruder CA, Parish S, Sasser RG Pregnancy-specific protein B in serum of postpartum beef cows. J Anim Sci. 1993:71:2199-205.

8. Han H, Austin KJ, Rempel LA, Hansen TR. Low blood ISG15 mRNA and progesterone levels are predictive of non-pregnant dairy cows. J Endocrinol. 2006;191:505-12.
9. Stevenson JL, Dalton JC, Ott TL, Racicot KE, Chebel RC. Correlation between reproductive status and steady-state messenger ribonucleic acid levels of the Myxovirus resistance gene, MX2, in peripheral blood leukocytes of dairy heifers. J Anim Sci. 2007;85:2163-72.

10. Green JC, Okamura CS, Poock SE, Lucy MC. Measurement of interferon-tau (IFN-T) stimulated gene expression in blood leukocytes for pregnancy diagnosis within 18-20d after insemination in dairy cattle. Anim Reprod Sci. 2010;121:24-33.

11. Shirasuna K, Matsumoto H, Kobayashi E, Nitta A, Haneda S, Matsui M, et al. Upregulation of interferon-stimulated genes and interleukin-10 in peripheral blood immune cells during early pregnancy in dairy cows. J Reprod Dev. 2012;58:84-90.

12. Matsuyama S, Kojima T, Kato S, Kimura K. Relationship between quantity of IFNT estimated by IFN-stimulated gene expression in peripheral blood mononuclear cells and bovine embryonic mortality after Al or ET. Reprod Biol Endocrinol. 2012;10:21.

13. Kizaki K, Shichijo-Kizaki A, Furusawa T, Takahashi T, Hosoe M, Hashizume K. Differential neutrophil gene expression in early bovine pregnancy. Reprod Biol Endocrinol. 2013:11:6.

14. Pugliesi G, Miagawa BT, Paiva YN, França MR, Silva LA, Binelli M. Conceptusinduced changes in the gene expression of blood immune cells and the ultrasound-accessed luteal function in beef cattle: how early can we detect pregnancy? Biol Reprod. 2014;91:95

15. Sakumoto R, Hayashi KG, Fujii S, Kanahara H, Hosoe M, Furusawa T, et al. Possible roles of CC- and CXC- chemokines in regulating bovine endometrial function during early pregnancy. Int J Mol Sci. 2017;18:742.

16. Humblot P. Use of pregnancy specific proteins and progesterone assays to monitor pregnancy and determine the timing, frequencies and sources of embryonic mortality in ruminants. Theriogenology. 2001;56: 1417-33.

17. Sakumoto R, Komatsu T, Kasuya E, Saito T, Okuda K. Expression of mRNAs for interleukin-4, interleukin-6 and their receptors in porcine corpus luteum during the estrous cycle. Domest Anim Endocrinol. 2006;31:246-57.

18. Takahashi T, Sakumoto R, Hayashi KG, Hosoe M, Shirai J, Hashizume K. Generation of recombinant bovine interferon tau in the human embryonic kidney cell line and its biological activity. Anim Sci J. 2017; 88:1498-505.

19. Balestrieri ML, Balestrieri A, Mancini FP, Napoli C. Understanding the immunoangiostatic CXC chemokine network. Cardiovasc Res. 2008;78:250-6.

20. Simon C, Caballero-Campo P, Garcia-Velasco JA, Pellicer A. Potential implications of chemokines in reproductive function: an attractive idea. J Reprod Immunol. 1998;38:169-93.

21. Hannan NJ, Salamonsen LA. Role of chemokines in the endometrium and in embryo implantation. Curr Opin Obstet Gynecol. 2007;19:266-72.

22. Townson DH, Liptak AR. Chemokines in the corpus luteum: implications of leukocyte chemotaxis. Reprod Biol Endocrinol. 2003;1:94.

23. Asselin E, Johnson GA, Spencer TE, Bazer FW. Monocyte chemotactic protein-1 and -2 messenger ribonucleic acids in the ovine uterus: regulation by pregnancy, progesterone, and interferon- $\tau$. Biol Reprod. 2001;64:992-1000.

24. Mansouri-Attia N, Oliveira LJ, Forde N, Fahey AG, Browne JA, Roche JF, et al. Pivotal role for monocytes/macrophages and dendritic cells in maternal immune response to the developing embryo in cattle. Biol Reprod. 2012;87:123.

25. Strieter RM, Burdick MD, Gomperts BN, Belperio JA, Keane MP. CXC chemokines in angiogenesis. Cytokine Growth Factor Rev. 2005;(6):593-609.

26. Nagaoka K, Sakai A, Nojima $H$, Suda $Y$, Yokomizo $Y$, Imakawa $K$, et al. A chemokine, interferon (IFN)- $\gamma$-inducible protein $10 \mathrm{kDa}$, is stimulated by IFN$\tau$ and recruits immune cells in ovine endometrium. Biol Reprod. 2003;68: $1413-21$.

27. Imakawa K, Nagaoka K, Nojima H, Hara Y, Christenson RK. Changes in immune cell distribution and $\mathrm{IL}-10$ production are regulated through endometrial IP-10 expression in the goat uterus. Am J Reprod Immunol. 2005:53:54-64.

28. Imakawa K, Imai M, Sakai A, Suzuki M, Nagaoka K, Sakai S, et al. Regulation of conceptus adhesion by endometrial CXC chemokines during the implantation period in sheep. Mol Reprod Dev. 2006;73:850-8.

29. Nagaoka K, Nojima H, Watanabe F, Chang KT, Christenson RK, Sakai S, et al. Regulation of blastocyst migration, apposition, and initial adhesion by a chemokine, interferon $\gamma$-inducible protein $10 \mathrm{kDa}$ (IP-10), during early gestation. J Biol Chem. 2003;278:29048-56. 
30. Dominguez F, Martínez S, Quiñonero A, Loro F, Horcajadas JA, Pellicer A, et al. CXCL10 and IL-6 induce chemotaxis in human trophoblast cell lines. Mol Hum Reprod. 2008;14:423-30.

31. Strieter RM, Burdick MD, Mestas J, Gomperts B, Keane MP, Belperio JA. Cancer CXC chemokine networks and tumour angiogenesis. Eur I Cancer. 2006;(6):768-78

32. Lasagni L, Francalanci M, Annunziato F, Lazzeri E, Giannini S, Cosmi L, et al. An alternatively spliced variant of CXCR3 mediates the inhibition of endothelial cell growth induced by IP-10, Mig, and I-TAC, and acts as functional receptor for platelet factor 4. J Exp Med. 2003;197:1537-49.

33. Cappello P, Caorsi C, Bosticardo M, De Angelis S, Novelli F, Forni G, et al. CCL16/LEC powerfully triggers effector and antigen-presenting functions of macrophages and enhances T cell cytotoxicity. J Leukoc Biol. 2004;75:135-42.

34. Mäkikallio K, Kaukola T, Tuimala J, Kingsmore SF, Hallman M, Ojaniemi M. Umbilical artery chemokine CCL16 is associated with preterm preeclampsia and fetal growth restriction. Cytokine. 2012;60:377-84.

35. Bussolino F, Mantovani A, Persico G. Molecular mechanisms of blood vessel formation. Trends Biochem Sci. 1997;22:251-6.

36. Strasly M, Doronzo G, Cappello P, Valdembri D, Arese M, Mitola S, et al CCL16 activates an angiogenic program in vascular endothelial cells. Blood. 2004;103:40-9.

37. Emond V, Asselin E, Fortier MA, Murphy BD, Lambert RD. Interferon-tau stimulates granulocyte-macrophage colony-stimulating factor gene expression in bovine lymphocytes and endometrial stromal cells. Biol Reprod. 2000;62:1728-37.

38. Oliveira JF, Henkes LE, Ashley RL, Purcell SH, Smirnova NP, Veeramachaneni $\mathrm{DN}$, et al. Expression of interferon (IFN)-stimulated genes in extrauterine tissues during early pregnancy in sheep is the consequence of endocrine IFN- $\tau$ release from the uterine vein. Endocrinology. 2008;149:1252-9.

39. Yang $L$, Wang $X L$, Wan $P C$, Zhang $L Y, W u$ Y, Tang DW, et al. Up-regulation of expression of interferon-stimulated gene 15 in the bovine corpus luteum during early pregnancy. J Dairy Sci. 2010;93:1000-11.

40. Shirasuna K, Matsumoto H, Matsuyama S, Kimura K, Bollwein H, Miyamoto A. Possible role of interferon tau on the bovine corpus luteum and neutrophils during the early pregnancy. Reproduction. 2015;150:217-25.

\section{Ready to submit your research? Choose BMC and benefit from}

- fast, convenient online submission

- thorough peer review by experienced researchers in your field

- rapid publication on acceptance

- support for research data, including large and complex data types

- gold Open Access which fosters wider collaboration and increased citations - maximum visibility for your research: over $100 \mathrm{M}$ website views per year 